\title{
THE STUCCO DECORATION OF THE MONUMENTAL ARCH ON THE DECUMANUS MAXIMUS AT HERCULANEUM
}

\section{CASO Marina ${ }^{1}$}

1 PhD in Classical Archaeology, Funzionaria Archeologa, Ministero per i Beni e le Attività Culturali, Parco Archeologico di Ercolano, Director dr. Francesco Sirano; marina.caso@beniculturali.it https://orcid.org/0000-0002-8639-4957

KEYWORDS: Herculaneum, tetrapylon arch, stucco decoration, chalcidicum, Decumanus Maximus

In the 1961, the open-air excavations directed by Amedeo Maiuri at Herculaneum reached its final phase as a stretch of the Decumanus Maximus was fully uncovered, ending near to where a monumental arch stands (Camardo \& Notomista, 2017, pp. 305-306, 318). ${ }^{\text {(Fig. 1) }}$

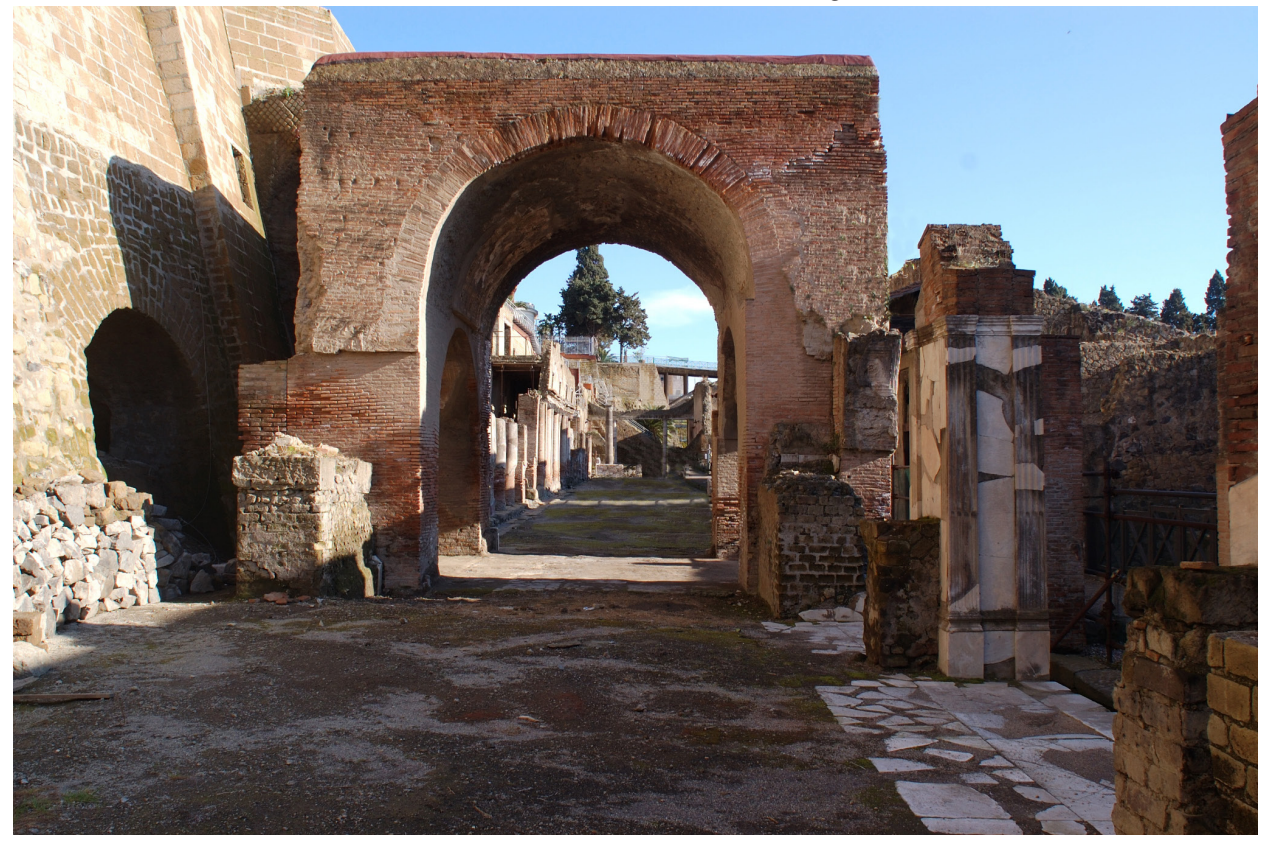

Fig. 1 Herculaeum. Tetrapylon arch from the west side (Photo by HCP Archive)

1 The excavation area is extended to the intersection with the upper Cardo III, to the College of the Augustales. 
Conserved immediately after its discovery, with the complete refacing of the piers, the arch had lost almost all its marble cladding, althought it retained stucco decorations on the upper portion of the south facade and within the intradoses. Maiuri partially recomposed the monument, although he did not use those stucco fragments which are stored in a cabinet in a workshop (VI, 16) on the Decumanus Maximus (Camardo \& Notomista, 2017, p. 250) and conserved and restored by advanced students of the Istituto Superiore per la Conservazione e il Restauro (ISCR), along with a small number of other stucco findings of various provenance.

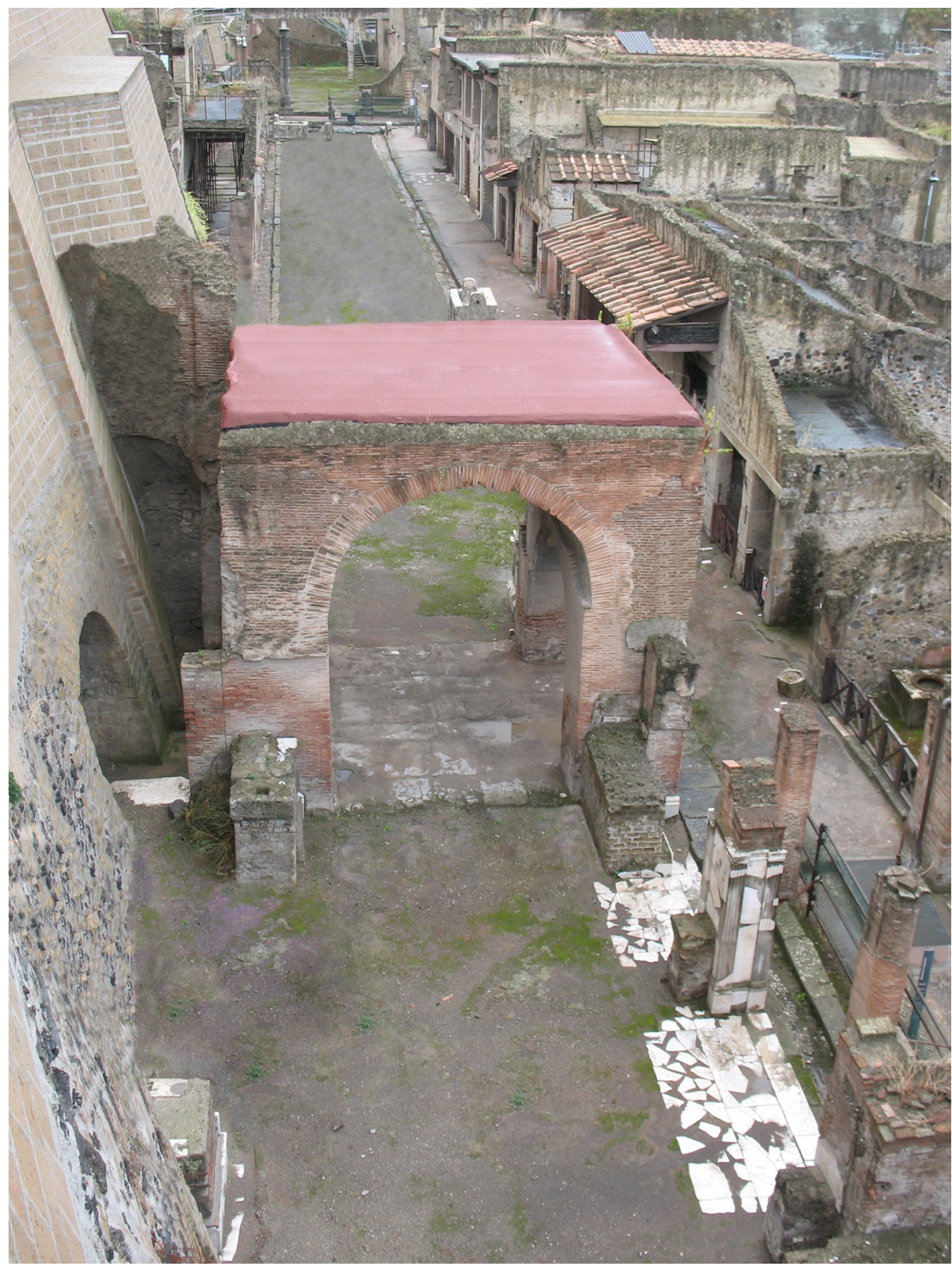

Fig. 2 Herculaneum. Chalcidicum, Tetrapylon arch and Decumanus maximus (Photo by HCP Archive) 
The arch, which today stands isolated on the Decumanus, restricting movement along the road, in fact formed the eastern part of a chalcidicum (Najbjerg, 2002, pp. 136 ff.; Allroggen-Bedel, 2008, pp. 37, 44-45). ${ }^{2}$ (Fig. 2)This is partly visible in excavated area as a raised marble-paved section that is delimited to the west by a second tetrapylon arch, which is still buried under the volcanic material and which was only partially exposed during recent archaeological research in the area of the Basilica Noniana. (Esposito \& Camardo, 2013, p. 221 ff.) In the mid-18 ${ }^{\text {th }}$ century, the Bourbon tunnel explorations reached this stretch of the Decumanus Maximus and found, among a considerable number of sculptures, the remains of a bronze quadriga that would have stood on the western arch, and which must have corresponded to a second one on eastern $\operatorname{arch}^{3}$. The two arches, at the edge of the portico, are sketched both in Pierre Bardet's plan of 1743 and in that of Jérôme - Charles Bellicard's one of 1754. (Allroggen-Bedel, 2008, p. 36 ff, figg. 1-4; Esposito, 2013, p. 223-225, Fig. 2, 3, 4, 5) The 18th-century graphic documentation illustrates an important area of the ancient city that has never been excavated. These plans show the location, beyond the northern edge of the current archaelogical site, of a building now commonly known as the Augusteum (Pagano, 1996, p. $240 \mathrm{ff}$; Allroggen-Bedel, 2008, p. 36-45 ). ${ }^{4}$ It would have been a large public square surrounded by porticoes, dedicated to the imperial cult ${ }^{5}$ the front of which would have been framed by the Chalcidicum. The $18^{\text {th }}$-century plans also depict the layout of the College of the Augustales on the opposite side, as well as the north-west corner of the Cardo III with the Basilica Noniana, which was re-examined in 2006. (Esposito, 2013, p. 231 ff.)
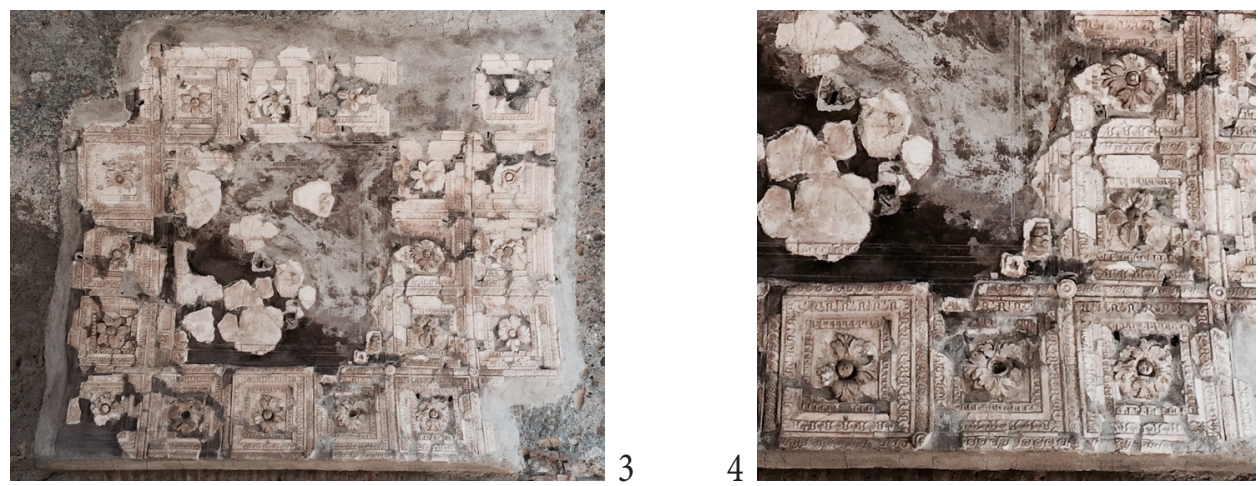

Fig. 3 Herculaeum. Tetrapylon arch, stucco decoration. Lacunars of the central vault (Photo by Marina Caso)

Fig. 4 Herculaeum. Tetrapylon arch, stucco decoration. Lacunars of the central vault, details (Photo by Marina Caso)

\footnotetext{
2 Regarding the architectural typology of the chalcidicum: Torelli, Mario 2003.

3 Fragments of the bronze quadriga found in the 18th century are in the National Archaeological Museum of Naples; see: Gabrici, 1907, pp. 1-12; Pannuti, 1983, p. 175; Esposito, 2013, p. 222, 227-228. On the Mazzocchi horse (MANN inv. 4904), the only element of the conserved and restored quadriga, and a horse's head, also pertaining to the sculptural group (MANN inv. 115391), see: Scatozza, 1989, p. 110; on the conservation-restoration: Prisco, 2008, p. 194 ff., fig. 5.
}

4 These publications with previous bibliography.

5 A summary of the hypothesis of use of the complex in Allroggen-Bedel, 2008, p. 44-45. 
The stucco relief decorations of the east arch cover the large central vault and the two sub-arches, to the north and south. (Mielsch, 1975, p. 49, 133, K 36, pl. 32) The central vault (Fig. 3) is decorated with a lacunar motif that develops between a braided motif: each recessed panel has the same frame decorated with a Lesbian kymation, a smooth intermediate band and a ribbed one that surrounds a six-petalled rosette, alternating with a less frequent second type with four poly-lobed petals (Fig. 4). The decorative scheme is more complex in the intradoses of the south (Fig. 5) and north arch (Fig. 6) where the moulding around the panels is decorated with astragalus and beads. The coffers towards the edge are quadrangular with a central rosette, alternating with rectangular ones which frame a rhombus with a central flower; the mouldings of the frames reflect the decorations of vault panels. In the central section a composition can be reconstructed that includes two adjacent quadrangular coffers, where a rectangular one decorated with a central rhombus and lozenges framing rosettes and, in sequence, a panel with a frame adorned with a ribbed decorative moulding, followed by a smooth band and a Lesbian kymation inside which are depicted recumbent Dionysian figures, identified by a thyrsus in the north scene and the pedum held in his left hand in the south one. The quadrangular lacunar motif is also found in the stucco decoration of one of the intradoses of the Chalcidicum arches, where a complex frame sees smooth mouldings alternating with mouldings decorated with ribbing and Lesbian kymation, surrounds a circular medallion (Fig. 7).
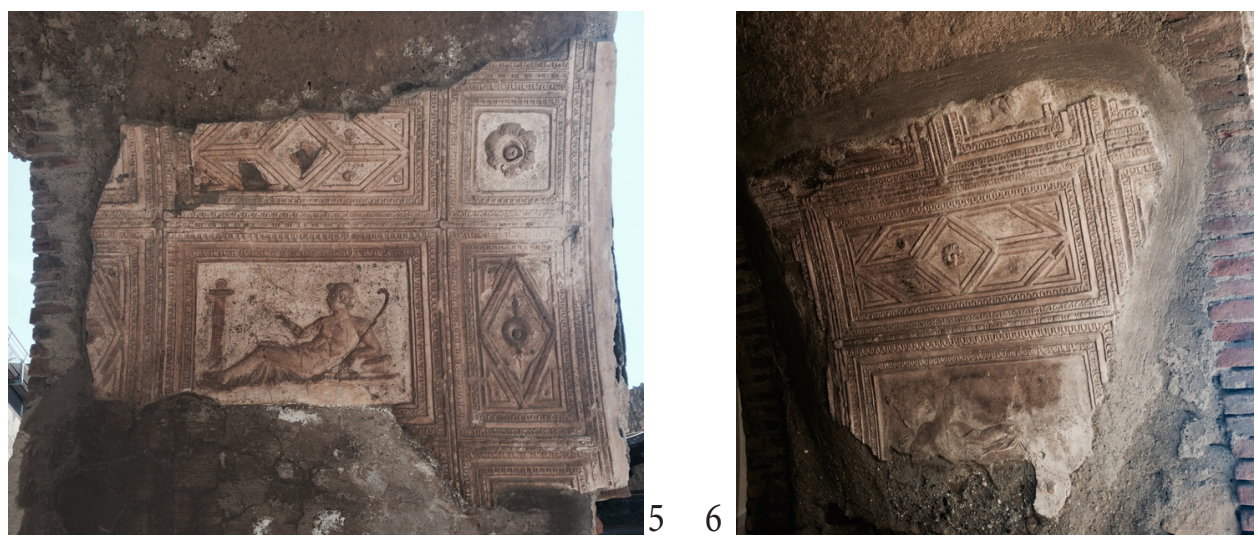

Fig. 5 Herculaeum. Tetrapylon arch, stucco decoration. The intrados of the south (Photo by Marina Caso)

Fig. 6 Herculaeum. Tetrapylon arch, stucco decoration. The intrados of the north (Photo by Marina Caso)

The arch's stucco work can be placed in the Neronian period by their decorative syntax and execution (Mielsch, 1975, pp. 49-50), inspired as they were by the compositional schemes of the sober classical rigour of late Republican tradition ${ }^{6}$, in a way that is entirely coherent with the solemn character of the related building complex.

The dating of the arch's stucco decoration would not be many years removed from that of the sculptural cycle of the Augusteum with its statues of the Julio-Claudian family members, donated by the Augustale L. Mammius Maximus around AD 50. (Allroggen-Bedel, 2008, pp. 37-40, 251-255) Instead the wall

\footnotetext{
6 See the stucco decorations of Villa of the Papyri, room of the first lower level with a stuccoed vault: Guidobaldi \& Esposito, 2012, p. 107 ff, figs. on p. 110-114.
} 
paintings of the later fourth style (Guidobaldi \& Esposito, 2012, p. $327 \mathrm{ff}$.), found during the Bourbon explorations of the Augusteum, can be attributed to a later phase, as can the imperial statues of the Flavian period, as part of a renewal of the building's decorative scheme.

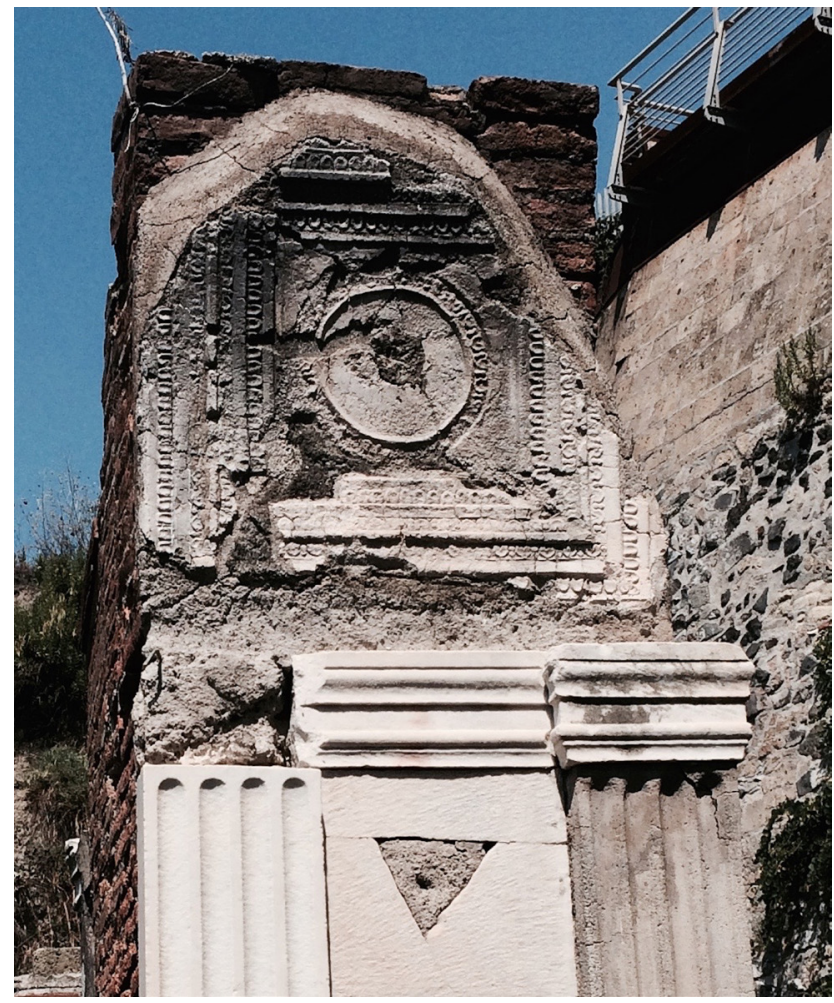

Fig. 7 Herculaeum. Chalcidicum arches, stucco decoration. One of the intradoses (Photo by Marina Caso)

The dating of the decorative features of the architectural complex, which the 18th-century plans suggest was a single unit, does not completely resolve all the issues related to the layout of the Augusteum and the chalcidicum in front of it, particularly regarding the evolving socio-political role that such an important location would have played over time within the urban fabric, through construction, reconstructions and renovations. In the absence of further archaeological data, however, it is possible to assume that the chalcidicum, obstructing passage along the Decumanus Maximus as it did, also defined the space in functional terms, establishing a significant topographical relationship with the Basilica and the College of the Augustales too ${ }^{7}$ - perhaps renewing of changing over time their original intended use - as well as with the public area of the city which still remains unexplored. ${ }^{8}$

On the architectural-functional links of Chalcidicum with the College of the Augustales: Najbjerg, 2002, p. 136, 145-146; Guidobaldi \& Esposito, 2012, p. 332-335.

8 With regard to the hypothesis on urban planning in this sector of the city, with particular reference to the location of the Forum and the Macellum, see Wallace-Hadrill, 2011, p. 157 (identification of the Forum with the Augusteum); Adamo Muscettola, 1982, p. 11; Allroggen-Bedel, 2010, p. 367-371; Esposito \& Camardo, 2013, p. 251-254. (hypothesis of placing the Forum to N/W of the public buildings identified on the Decumanus Maximus). 


\section{Bibliography}

Adamo Muscettola, S. (1982). Nuove letture borboniche. I Nonii Balbi ed il Foro di Ercolano, Prospettiva 1982, pp. 2-16.

Allroggen-Bedel, A. (2008). L'Augusteum. In: Guidobaldi, M. P. (Ed.). (2008). Ercolano. Tre secoli di scoperte (pp. 34-45). Catalogo della mostra, Milano: Mondadori Electa.

Allroggen-Bedel, A. (2010). A proposito dei Balbi. Note archivistiche alla topografia d'Ercolano. In: Gasparri, C., Greco, G. \& Pierobon Benoit, R. (Eds.), Dall'immagine alla storia. Studi per ricordare Stefania Adamo (pp. 355-373). Pozzuoli: Naûs.

Camardo, D. \& Notomista, M. (2017). Ercolano 1927-1961. L'impresa archeologica di Amedeo Maiuri e l'esperimento della città museo. Roma: L'Erma di Bretscheneider.

Esposito, D. \& Camardo, D. (2013). La Basilica Noniana di Ercolano. RM 119, pp. 221-258.

Gabrici, E. (1907). La quadriga di Ercolano. BdA 1, pp. 1-12.

Guidobaldi, M. P. \& Esposito, D. (2012). Ercolano. Colori da una città sepolta. Verona: Arsenale.

Mielsch, H. (1975). Römische Stuckreliefs, RM, Suppl. 21.

Najbjerg, T. (2002). A Reconstruction and Reconsideration of the so-called Basilica in Herculaneum. JRA, suppl 47, pp. 122-165.

Pagano, M. (1996). La nuova pianta della città e di alcuni edifici pubblici di Ercolano. CronErcol 26, pp. 229-257.

Pannuti, U. (1983). Il Giornale degli scavi di Ercolano (1738 - 1756). MemLinc 26,3, pp. 161-410.

Prisco, G. (2008). Restauri per via di mettere, restauri per via di togliere. Alla ricerca di un metodo nelle officine di Portici. In Cantilena, R. (Ed.). Herculanense Museum. Laboratorio sull'antico nella Reggia di Portici (pp. 189-207. Milano: Mondadori Electa.

Scatozza, L. A. (1989). La scultura greco-romana. In: Archivio Fotografico Pedicini (Ed.). Le collezioni del Museo Nazionale di Napoli. Roma-Milano: De Luca - Leonardo.

Torelli, M. (2003). Chalcidicum. Forma e semantica di un tipo edilizio antico. Ostraka 12, pp. 215-238. Wallace-Hadrill, A. (2011). The Monumental Centre of Herculaneum in Search of the Identities of the Public Buildings. JRA 24, pp. 121-160. 